University of Wollongong

Research Online

Faculty of Arts - Papers (Archive)

Faculty of Arts, Social Sciences \& Humanities

July 2003

\title{
When does gender trump money? Bargaining and time in household work
}

\author{
M. Bittman \\ University of New South Wales \\ P. England \\ Northwestern University, USA \\ L. Sayer \\ Ohio State University, USA \\ N. Folbre \\ University of Massachusetts, USA \\ George Matheson \\ University of Wollongong, gmath@uow.edu.au
}

Follow this and additional works at: https://ro.uow.edu.au/artspapers

Part of the Arts and Humanities Commons, and the Social and Behavioral Sciences Commons

\section{Recommended Citation}

Bittman, M.; England, P.; Sayer, L.; Folbre, N.; and Matheson, George, When does gender trump money? Bargaining and time in household work 2003.

https://ro.uow.edu.au/artspapers/85

Research Online is the open access institutional repository for the University of Wollongong. For further information contact the UOW Library: research-pubs@uow.edu.au 


\title{
When Does Gender Trump Money? Bargaining and Time in Household Work ${ }^{1}$
}

\author{
Michael Bittman \\ University of New South Wales
}

Paula England

Northwestern University

Liana Sayer

Ohio State University

Nancy Folbre

University of Massachusetts, Amherst

George Matheson

University of Wollongong

\begin{abstract}
Using data from Australia and the United States, the authors explore the effect of spouses' contribution to family income on how housework is divided. Consistent with exchange-bargaining theory, women decrease their housework as their earnings increase, up to the point where both spouses contribute equally to income. In other respects, gender trumps money. The base level of housework for women is much higher. Among the small percentage of couples who are in the range where women provide $51 \%-100 \%$ of household income, the change in housework is opposite what exchange theory predicts: couples that deviate from the normative income standard (men make more money than women) seem to compensate with a more traditional division of household work.
\end{abstract}

Wives do much more housework than husbands. For example, time-diary data on housework, excluding child care, show that in 1992 Australian husbands averaged 11 hours per week while their wives averaged 23 hours. The most comparable data from the United States show husbands doing 13 hours per week while wives do 18 (Bianchi, Robinson, and Sayer 2001). ${ }^{2}$ Two perspectives dominate past sociological work on how couples

\footnotetext{
${ }^{1}$ We thank the MacArthur Foundation's Network on the Family and the Economy and the National Institutes of Health's postdoctoral fellowship to Liana Sayer for support. Address correspondence to Paula England, 1810 Chicago Avenue, Northwestern University, Evanston, Illinois 60208. E-mail: P-England@northwestern.edu

${ }^{2}$ 'The median hours are 8 and 24 for Australia and 7 and 14 for the United States.

(C) 2003 by The University of Chicago, All rights reserved 0002-9602/2003/10901-0005 $\$ 10.00$
} 
allocate time to household work. ${ }^{3}$ Exchange theory suggests that power flows from bringing resources to a relationship and that a spouse can use economically based bargaining power to get the other partner to do housework. Similar predictions come from game theoretic bargaining models used by economists. In this exchange-bargaining view, money talks: men in two-earner families typically do less housework than their wives because they earn more, and women can parlay earnings into bargaining for a reduction in their own or an increase in their husbands' housework. In this view, gender affects the doing of housework indirectly, through its effect on relative earnings.

A second sociological view emphasizes that gender has pervasive effects at many levels, structuring identities, norms, interaction, and institutions. In this view, gender not only affects housework indirectly, through earnings, but also affects it in other ways, through gendered expectations. These views are not mutually exclusive. Our goal is to ascertain whether earnings affect who does how much household work and to identify where other gender constraints override this pattern. One type of gender constraint we will consider is the possibility that when men earn less than women, couples respond to this "gender deviance" by increasing traditionality in housework. This compensation is the opposite of what exchange theory predicts.

The main contribution of our article is to clarify the ways and situations in which "money talks" in determining housework, in keeping with exchange-bargaining theory. Our second contribution is to identify other ways in which gender has effects, including "other things equal" gender ascription as well as processes in which gender traditionality in household work appears to be in compensation for deviance from norms prescribing male economic provision.

We analyze data from the 1992 Australian National Time-Use Survey (AN'TUS) to address these questions, taking advantage of its high-quality measures of time spent in household work from time diaries collected from a large probability sample. We also compare these findings to recent findings by Brines (1994), Gupta (1999b), and Greenstein (2000) on U.S. data and to our own reanalysis of one of the American data sets (the National Survey of Families and Households, or NSFH). This comparison notes similarities and differences between the two nations in the extent to which time spent on household work responds to the relative earnings

\footnotetext{
${ }^{3}$ We use the terms housework, household work, unpaid work, and nonmarket work synonymously. We refer to work done without pay to include work around the house and yard. In principle, terms could include shopping and child care, although our analyses will exclude these for comparability with past studies.
} 
of spouses. We offer some speculations about the institutional sources of the differences.

\section{EXCHANGE AND BARGAINING MODELS}

Sociological exchange theory provides one way to think about the effect of relative earnings on housework allocation. This tradition assumes selfinterested actors, and at first this seems a strange notion to apply to relationships based on commitment and love. However, the divorce rate indicates that many people are not unconditionally committed to their marriages and that selfish behavior is certainly not absent from marriage. This opens the possibility that the model has some explanatory power for couples.

Consider two spouses, A and B. The power-dependence tradition of exchange theory states that if $\mathrm{A}$ is economically more dependent on $\mathrm{B}$, A will give more and receive less in the exchange (than $A$ would if less dependent). $\mathrm{A}$ is seen as more dependent on $\mathrm{B}$ to the extent that she or he has limited access to resources other than through B. Why does exchange theory predict that "money talks"? The idea is that A's dependence lowers his or her rewards because $\mathrm{A}$ is unlikely to stop (or reduce) exchanges with $\mathrm{B}$ if $\mathrm{A}$ has little access to resources except through $\mathrm{B}$. Knowing this, B does not have to give so much to keep A exchanging. The dependence of $\mathrm{A}$ increases what $\mathrm{A}$ has to give, or decreases what $\mathrm{B}$ has to give, in exchanges between the two. Applying this to marriage suggests that alternative exchange opportunities could include things such as sources of income (via labor or marriage markets or a state safety net). These may be alternatives that one would have to leave the marriage to pursue, or they may be alternatives within the marriage. (For an overview of exchange theory, see Molm and Cook [1995] and Cook [1987]. For applications to marital power, see Heer [1963], Scanzoni [1979], Molm and Cook [1995, p. 220].)

Roughly the same predictions are generated from recent bargaining models proposed by economists, based on game theory. The similarity in predictions flows from the fact that both traditions assume that individuals engage in self-interested behavior. Bargaining models, only recently applied by economists to family behavior," deploy the notion of "threat

\footnotetext{
${ }^{4}$ Another dominant economic model of the family is that of Gary Becker (1991), who assumes altruism among family members and a single family utility function. In Becker's analysis, spouses agree on a division of labor between market and household work that maximizes output for the whole family. There is no notion that the partner who earns more has more power to get his or her way, as in bargaining or exchange theory.
} 
points" (McElroy 1990; McElroy and Horney 1981; see Lundberg and Pollak [1996] for an overview). Divorce threat point (or external threat point) models emphasize that bargaining within marriage is conducted in the shadow of the possibility of divorce. An individual's "threat point" is what she or he has to fall back on if the marriage dissolves-for example, how much one earns, access to other income (e.g., from child support or the state), or position in the "remarriage market." In this view, the worse off $A$ would be if the marriage dissolved, the less $B$ has to provide $A$ in the marriage. If both spouses act this way, it follows that the better B's alternatives for utility outside (relative to inside) the marriage, or the worse A's alternatives outside (relative to inside) the marriage, the better a bargain B (and worse A) can strike in the marriage. In sum, resources that one would withdraw from one's partner and/or retain for oneself if the marriage dissolved increase bargaining power.

Another version of the bargaining model (Lundberg and Pollak 1993, 1996) considers threat points internal to the marriage. Here the issue is what one spouse can withhold from the other without leaving the marriage and what that leaves the other to fall back on within the marriage. In this view, money that comes into the household through one partner affects the balance of power because the earner could possibly fail to share some or all of the income, even if divorce is never considered an option.

Exchange-bargaining theories say nothing about the content of the conversational sequences through which bargaining occurs. It may be that no verbal bargaining is needed because each partner perceives the best deal he or she can get, given the relative resource situation. Even if there is verbal bargaining, the view does not require that threats are discussed (as in "I'll file for divorce if you don't start doing the dishes"). The theories focus on how resources affect the "struck bargain." If we assume that most people would prefer to do less housework, then exchange-bargaining theories predict that the higher spouse B's earnings relative to A's, the more housework A will do and the less B will do.

This view is consistent with some evidence regarding who does how much housework. Five sociological studies (Ross 1987; Presser 1994; Brines 1994; Gupta 1999b; Greenstein 2000) have found that the effects of relative earnings on the division of housework are such that women do less or men do more as women's earnings increase, at least in the range from husbands' providing all the income to both partners' having equal earnings. In our view, one weakness of these studies is that they do not adequately control for hours of employment of both spouses. ${ }^{5}$ Since hours

\footnotetext{
${ }^{5}$ Ross (1987) controlled for wives' employment status-not employed, employed parttime, or employed full-time-but not for hours per week, within either the part- or full-time category, or for husbands' hours of paid work. Brines (1994) and Gupta
} 
and weeks of employment during the year strongly affect annual earnings, some of what these studies are picking up may simply be that one works more hours in the market. This is consistent with what some sociologists call the "situational" or "time availability" view (Shelton 1992). It is also consistent with Becker's (1991) notion that spouses divide labor efficiently to maximize benefits to the family as a whole. But, unlike these views, the exchange-bargaining view entails the hypothesis that a man or woman with higher relative earnings will have the power to get the other spouse to do more housework even if this spouse works just as many hours in the market and thus has to forgo leisure to do the housework.

\section{MULTILEVEL EFFECTS OF GENDER}

Gender operates at multiple levels-individual, interactional, cultural, and institutional (Ferree, Lorber, and Hess 1998)-with complicated causal paths between them. Labor markets yield unequal earnings for men and women, and the idea that this inequality affects household bargaining through affecting exchange processes would not surprise gender scholars. However, most scholars of gender believe that, precisely because gender operates at so many levels, a gender-neutral model of bargaining or exchange is unlikely to be adequate (Wilkie, Ferree, and Ratcliff 1998). One way that gender could affect the allocation of housework even in the absence of unequal earnings is through the norms internalized by men and women. Such norms would lead women to feel that they should do or want to do housework, but lead men to have no such desire or sense of responsibility. Or the norms may involve a tacit assumption that housework is to be done by women, an assumption so taken for granted that it is seldom thought about."

Recently, many sociologists of gender have eschewed the traditional view of norms (described above) in favor of the notion of "doing gender" (see Coltrane [2000] for an overview). This view of gender was pioneered by West and Zimmerman (1981) and applied to household work by Fenstermaker Berk (1985) and South and Spitze (1994). The idea is that individuals' behavior is affected by the expectations held by others. In this view (unlike, say, a rational-choice view of norms in which we follow

(1999b) controlled for whether or not women were "housewives," and whether husbands and wives were employed full-time, part-time, or unemployed on a short-term or longterm basis. But they did not control for hours of paid work among either full-time or part-time workers. But Presser (1994) did. Greenstein (2000) controlled for the respondent's hours of paid work but not for those of his or her spouse.

"Some recent writings by heterodox economists have also invoked norms to cxplain couples' division of household work (Katz 1997; Agarwal 1997; Lundberg and Pollak 1993, 1996). 
norms to get rewards or avoid punishments, including approval or disapproval), social influence can proceed even without carrots and sticks. To make cognitive sense out of the world, individuals behave in ways that they can explain to others, and this leads them to follow others' expectations, including those related to gender. In this view, actors do not necessarily internalize gendered identities or norms they really believe are morally right or preferable, but rather they internalize only expectations that others will follow norms along with a need to present themselves as cognitively "making sense" in terms of these norms. If this is true, then it is the combination of our need to make sense to each other and our holding of expectations of others' behavior that constrains us all to act in normative ways.

We will not be able to ascertain whether observed gendered processes that cannot be predicted from relative earnings operate through internalized assumptions, preferences, or values, as in the traditional view of internalized norms, or through pressures to render oneself "accountable" by "doing gender." But either view suggests pressures for women to do and men to avoid doing housework, above and beyond what can be explained by relative earnings.

What do we know about the role of gender from past studies of household work? The major conclusion is that women do more and men less household work even when market hours are fairly equal, and relative earnings explain some but only a small share of the variance in which men or women do more. Some studies (reviewed in Greenstein 2000) find that traditional gender beliefs lead men to do less and women to do more household work. Both American and Australian opinion polls show a clear egalitarian trend in attitudes toward the gender division of labor (Badgett, Davidson, and Folbre 2000; Bittman and Pixley 1997). However, correlations between abstract gender role norms and housework behavior, while present, are very small (Wilkie et al. 1998). Behavior is much less egalitarian, and has changed much less, than attitudes. To be sure, men's hours of household work have increased in the United States since 1965, although the increase in women's paid work hours and decrease in their household work hours are much more dramatic (Bianchi et al. 2000).

Bittman and Pixley (1997, p. 113) review evidence showing that, even when both Australian partners are working full-time, women still do an overwhelmingly large proportion of laundry, physical child care, cooking, and cleaning. In a U.S. sample, Fenstermaker Berk (1985) showed that when spouses both worked full-time, wives often did several hours of household work at night while husbands did less than one. Hochschild (1989, pp. 221, 277-78) found that even among U.S. couples with equal earnings, only $30 \%$ shared household work relatively equally. Thus, it is clear from both Australian and American data that, even in the unusual 
cases where women and men spend equal hours in paid employment or have equal earnings, men do substantially less household work. Ascription by sex appears pervasive.

The salience of gender is also shown by the fact that, whatever independent variables are used, most seem to affect women's housework time much more than men's. Studies predicting men's and women's hours of household work separately find a much higher proportion of variance explained for women than for men, irrespective of what variables are put in the model (e.g., Brines 1994; Greenstein 2000). For example, Brines's (1994) models explain about a quarter of the variance in women's household labor time but only about a tenth of men's.

Where studies do find factors that affect men's housework, these do not always fit predictions from exchange theory. For example, Hochschild (1989) notes that, among couples in their sample where women earned more than men, none shared the housework equally, whereas $21 \%$ of couples where men had higher earnings and $30 \%$ of those with equal earnings did so. Contrary to exchange theory, the men who had the lowest relative earnings shared least. (However, the study entailed only $100 \mathrm{cou}-$ ples, and differences were not statistically significant.) Similarly, Atkinson and Boles (1984) found that women did most of the household work in marriages where the woman's career and earnings predominated. Their qualitative interviews showed that the couples were often influenced by others' perceptions that their decision to prioritize the woman's career was deviant and stigmatizing for the man, and hence they felt the need to come up with a number of deviance neutralization strategies.

These scattered findings suggest a generalization tested more systematically by Brines (1994) and Greenstein (2000). Both found that men's hours of housework increased as the share of income provided by women increased, up to the point where women contributed equally, just as exchange theory would predict. But beyond that point men reduced their housework contributions as women's share of income provision continued to increase. Brines and Greenstein differ on how to interpret this, as we detail below. However, they agree that when men are earning substantially less than their wives, this violates gender norms and leads either the wife or the husband (or both) to move to more traditional behavior in the realm of housework in order to neutralize the deviance. Brines uses the concept of "gender display." She argues that, while wives' employment is now acceptable, husbands are still not supposed to be dependent. When wives earn more than half the income, gender norms are being violated. In this situation, husbands may be especially unwilling to do housework or wives may be disinclined to push them to do so, because it would "feminize" the men even more. Thus, in Brines's view, it is precisely where income provision does not allow men to "display gender" that one or both 
members of the couple will decide to free men from most of the domestic work to avoid even further gender deviance.?

Greenstein (2000) believes that the findings should be interpreted in terms of "deviance neutralization," which he sees as a more general concept than Brines's notion of "gender display." However, when the deviance in question is men's failure to provide a majority of a couple's income, it is deviance from a norm about gender. Perhaps the best term that combines the insights of Brines and Greenstein is "gender deviance neutralization." Using the NSFH, Greenstein replicates Brines's Panel Study of Income Dynamics (PSID) result of a curvilinear effect on men's housework of the proportion of income women contribute. Like Brines, he finds the curvilinear effect for men but not for women. ${ }^{9}$ For women, the effect of relative earnings is as predicted by exchange theory.

\footnotetext{
"Brines chose the term "gender display" to allow the possibility of either internalized states or behavior undertaken being accountable to external expectations (Brines, personal communication to Paula England in 2000).

${ }^{8}$ Greenstein (2000) also disputes Brines's (1994) reasoning about why the proportion of income provided by wives has a nonlinear effect on men's, but not women's, household work. Brines's a priori theoretical prediction was that what we are calling gender deviance neutralization would affect $b o t h$ husbands' and wives' housework nonlinearly such that, as women's contributions moved beyond half of family income, women's housework would go up and men's would go down. She found the nonlinearity only for men (it was not significant for women). In seeking a post hoc interpretation, Brines suggested that it is because of twin asymmetries in conceptions of "male" and "female." The male role is seen as more of a problematic accomplishment than the female role (which is seen as "natural"), and maleness is defined in terms of a rejection of femaleness (femaleness is not seen as rejecting maleness). Thus, the "hard work" of being a man is quintessentially about avoiding being like a woman. We agree with Brines that this asymmetry is fundamental to gender constructions, but we agree with Greenstein that it does not imply that when men earn less than their wives this will evoke a reduction in men's housework but not in women's. If being male is defined in a relative way, a husband's relative "maleness" can change either through her increase in housework or through his decrease.

"Greenstein (2000) also calculates the proportion of the household work done by each spouse and estimates separate models predicting this proportion from relative earnings. He finds that both men's and women's proportion is affected by men's cconomic dependency, in the directions predicted by deviance neutralization. Of course, if husbands and wives were the only family members whose housework contributions were included, then the wife's percentage would be defined by 100 minus the husband's percentage, and, by definition, any factor that affected husbands' share positively would affect wives' share negatively to the same extent. In the NSFH data, husbands' and wives' housework constituted $94 \%$ of the total. Greenstein's finding that economic dependency affects wives' as well as husbands' share of housework does not contradict the possibility that this is all coming from its effect on husbands' absolute hours. Indeed, his finding that women's absolute hours do not go down as they move from providing equal to all the income suggests that the effect is coming from husbands. Thus, Greenstein has not, in our view, shown that gender deviance neutralization is coming from women's as well as men's behavior in the U.S. context.
} 
Gupta (1999b), however, provides an important caveat to conclusions reached by Brines (1994). He replicates Brines's PSID analysis and shows that if one eliminates the extreme tail of the distribution of husbands' relative earnings (as little as $3 \%$ of couples), the curvilinearity disappears. Thus, while it is true that men reduce rather than increase their housework as earnings move from equality to women providing all the income, that result actually comes exclusively from the small number of men with the lowest earnings relative to their wives. Hence, the American data suggest that, in most of the population, which men (and which women) will be doing more housework fits exchange theory quite well, although the higher base level of housework done by all women is consistent with strong gender effects. ${ }^{10}$ We will look for both of these gender effects in our dataa higher base level of housework for women, net of hours of employment, and the nonlinearity by which couples respond to the gender deviance of men's earning less than women by increasing the traditionality of their housework allocation.

\section{DATA}

Our main analysis is based upon data from a 1992 time-diary survey conducted in Australia. (International specialists in time use agree that time diaries are the most accurate method of data collection.) We compare our findings to those from past studies on U.S. data sets that contain information on time use, the 1985 PSID (used by Brines [1994] and Gupta [1999b]) and the 1987 NSFH (used by Presser [1994], South and Spitze [1994] and Greenstein [2000]). In the appendix to the article, we also present our own calculations from the U.S. NSFH data, undertaken to maximize comparability with the procedures utilized in our Australian data. Since this analysis is not our main focus, we do not describe the data set here but refer the reader to Greenstein (2000), who used the data for one of the studies to which we compare our results. The data are also described in Sweet, Bumpass, and Call (1988). Unfortunately, the U.S. results are not based on time-diary data, because there is no U.S. data set from time diaries that contains measures of unpaid work as well as measures of earnings. The only recent time-diary data available, those collected in 1985 (Robinson and Godbey 1997), and those collected in 1995 (Bianchi et al. 2000; Bianchi et al. 2001), are inappropriate for this inquiry

${ }^{10}$ Using the NSFH, Gupta (1999a) shows that the same man does less housework when he begins to cohabit or marries than he did previously, while women increase their housework upon marriage or beginning to cohabit. He takes this as consistent with the "doing gender" perspective since it shows that the same person engages in different housework behavior when in a different relational situation. 
because they do not contain measures of individuals' earnings. U.S. data containing measures of earnings as well as questions about time in household work simply asked respondents how many hours per week they spent in various types of housework. This method is more susceptible to lack of recall and to social-desirability bias than the time-diary method. However, while simple questions on hours per week do tend to evoke exaggerated accounts of housework hours by both men and women, the ratio of men's to women's reports does not differ appreciably between the two types of studies (Bianchi et al. 2000). "This provides some warrant for using the two different measurement strategies for comparing the effects of relative earnings on housework across studies. (For methodological discussions and studies comparing the time diary to the "stylized question" method, see Hill and Stafford [1985], Juster [1985], Robinson [1985], Marini and Shelton [1993], Niemi [1993], Pallié [1993], Frederick [1995], Robinson and Godbey [1997], and Bianchi et al. [2000].)

The data we use for our main analysis are from the first Australian national time use survey which used the time-diary method and was collected by the Australian Bureau of Statistics in 1992 (ABS 1993). Time diaries were collected on designated days from a random sample of households at four separate periods over the calendar year (with the aim of capturing seasonal variation). Two-day diaries were completed by each of approximately 7,000 persons over 15 years of age in approximately 4,000 households in the national probability sample. In households with a married or cohabitating couple, data were collected for both persons. (We treat cohabiting couples as de facto married, following the Australian government's convention.)

Based on five-minute time intervals, the diaries asked respondents to record their main activity in each interval. (They were also asked if they were doing anything else at the same time, but we do not use these "secondary activities" in our analyses.) The survey sample contained 13,937 diary days. For the purposes of this analysis, the sample was restricted to households containing a couple. To exclude retirees, we excluded couples in which either spouse was over 55 years of age, although we have ascertained in results not shown that our major conclusions are the same if they are included. In order to separate the effect of disability and low earnings, we excluded couples in which either partner reported a disability that impaired employment. In addition, for reasons involving the limitations of the income measure detailed below, couples in which

\footnotetext{
${ }^{11}$ The mean weekly housework reported for husbands and wives, respectively, in the NSFH is 16.8 and 34.8 (medians are 13 and 30). This compares with means of 12.8 and 18.1 for husbands and wives in U.S. time-diary data (and medians of 7 and 14) (Bianchi et al. 2001).
} 
either person reported that he or she had individual income but that the main source of that income was unearned (government pension, or investments) were excluded (although couples where one partner had no income were not excluded). Out of a total of 3,913, this left 2,244 couple diary days that were not removed by any of our exclusions and had no missing values for either spouse on which to base our analysis.

\section{Variables}

Table 1 contains the list of variables used in the analyses discussed below, with their means and standard deviations. These descriptive statistics are shown separately for husbands and wives.

Dependent variable._Our major dependent variable is time spent in domestic work. More specifically, it includes food and drink preparation and meal cleanup; laundry, ironing, and clothes care; tidying, dusting, scrubbing, and vacuuming; paying bills and household management; lawn, yard, pool, and pet care; and home maintenance and car care. For comparability with the major U.S. studies, we excluded child care and shopping. ${ }^{12}$ For ease of interpretation, daily hours were converted to hours per week. The quality of this measure is very high by international standards. Activities were initially coded into a three-digit classification, which was then mapped to a 75-activity classification, compatible with internationally standardized measures of housework used in time-diary studies in affluent nations other than the United States (ABS 1993). Juster (1985) and Robinson (1985) have shown that the average number of episodes is a good indicator of the quality of diary data. An average of more than 25 episodes per day indicates higher than usual data quality. The mean number of episodes per day in the Australian survey is more than 30 (ABS 1993).

Independent variable.-A measure of relative income contributions is needed to isolate the effects predicted by exchange-bargaining theories. We use a measure proposed by Sorensen and McLanahan (1987) and used by Brines (1994). The wife's annual income is subtracted from the husband's, then divided by the total of their two incomes, leading to a scale score of 1 where the husband provides all the income, 0 when each contributes equal shares, and -1 when the wife provides all the couple's income. For simplicity, we have rescaled this into a variable correlated perfectly with these two earlier studies but ranging instead from 0 to 1

\footnotetext{
12 While Greenstein's (2000) analysis of the NSFH includes grocery shopping, we thought comparability was maximized by excluding shopping from our Australian measure because it includes all types of shopping. However, our major conclusions remain the same if shopping is included.
} 
TABLE 1

MEANS ANd SDS For Major Variables

\begin{tabular}{|c|c|c|}
\hline Variable & Husbands & Wives \\
\hline Weekly hours of housework ..... & $\begin{array}{l}11.04 \\
(14.07)\end{array}$ & $\begin{array}{c}23.28 \\
(15.99)\end{array}$ \\
\hline Husband's share of income (scaled 0-1) ... & $\begin{array}{l}.70 \\
(.27)\end{array}$ & $\begin{array}{l}.70 \\
(.27)\end{array}$ \\
\hline Husband's share of income ${ }^{2} \ldots$ & $\begin{array}{l}.56 \\
(.34)\end{array}$ & $\begin{array}{l}.56 \\
(.34)\end{array}$ \\
\hline Combined weekly income ${ }^{a}$ & $\begin{array}{c}883.55 \\
(453.02)\end{array}$ & $\begin{array}{l}883.55 \\
(453.02)\end{array}$ \\
\hline Saturday $(1=$ yes $)$. & .15 & .15 \\
\hline Sunday $(1=$ yes $)$ & .15 & .15 \\
\hline Number of children: & & \\
\hline Less than two years old & $\begin{array}{l}.16 \\
(.39)\end{array}$ & $\begin{array}{l}.16 \\
(.39)\end{array}$ \\
\hline Ages $2-4 \ldots \ldots \ldots \ldots \ldots$ & $\begin{array}{l}.20 \\
(.44)\end{array}$ & $\begin{array}{l}.20 \\
(.44)\end{array}$ \\
\hline 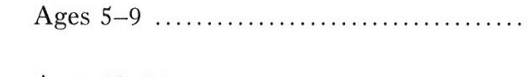 & $\begin{array}{l}.35 \\
(.64)\end{array}$ & $\begin{array}{l}.35 \\
(.64)\end{array}$ \\
\hline Ages $10-14 \quad \ldots \ldots \ldots \ldots$. & $\begin{array}{l}.37 \\
(.66)\end{array}$ & $\begin{array}{l}.37 \\
(.66)\end{array}$ \\
\hline Usual weekly hours of paid work .......... & $\begin{array}{c}46.61 \\
(15.9)\end{array}$ & $\begin{array}{c}23.82 \\
(18.82)\end{array}$ \\
\hline University degree $(1=$ yes $) \ldots \ldots \ldots \ldots \ldots$ & 18 & .12 \\
\hline Trade qualifications $(1=$ yes $) \ldots \ldots \ldots \ldots$ & .30 & .04 \\
\hline Has high school diploma $(1=$ yes $) \ldots \ldots .$. & 11 & .11 \\
\hline Age & $\begin{array}{l}38.46 \\
(8.29)\end{array}$ & $\begin{array}{c}36.19 \\
(8.32)\end{array}$ \\
\hline Unemployed $(1=$ yes $) \ldots \ldots \ldots \ldots \ldots \ldots \ldots$ & .02 & .03 \\
\hline Out of labor force $(1=$ yes $) \ldots \ldots \ldots \ldots \ldots$ & .01 & .20 \\
\hline $\begin{array}{l}\text { Evenly split self-employment income }(1= \\
\text { yes) } \ldots \ldots \ldots \ldots \ldots \ldots \ldots \ldots \ldots \ldots \ldots \ldots \ldots \ldots \ldots \ldots \ldots \ldots \ldots \ldots \ldots\end{array}$ & .04 & .04 \\
\hline
\end{tabular}

NOTE. $-N=2,244$.

a The average weekly income of both husband and wife is given in Australian dollars.

and indicating the proportion of income contributed by the husband. ${ }^{13}$ Following Brines (1994), Gupta (1999b), and Greenstein (2000), we enter the linear and squared form of the husband's proportion of family income to see if the effect of spouses' relative contribution to income was nonlinear in a way consistent with gender deviance neutralization. (We also entered the cubed form, but it was never significant.)

ANTUS asked each spouse to report her or his own income from all sources. A separate question asked whether the main source of this income

${ }^{13}$ However, this rescaling reverses the sign on the squared term from that predicted by Brines (1994). 
was from wages or salaries, earned income from self-employment, investments, private pensions, or government payments. Unfortunately, in those cases where individuals had multiple sources, a separate amount from each source was not given. We use this report of annual personal income but delete from our analysis all individuals who reported the main source as coming from anything other than earnings (wages, salaries, or self-employment). Thus, only couples in which each reported either no income (e.g., a housewife or unemployed person) or earned income as his or her main source of individual income were included. Respondents could report income as weekly, monthly, or annual, but we have converted it to a weekly metric. ${ }^{14}$ But respondents reported their total personal income from all sources. Thus, our attempt to measure earned income only succeeds insofar as we exclude all couples where either has his or her major source of income as investment, pension, or a government program; a weakness of the measure is that it does include some government or investment income for individuals whose main source was earned income. Given the limits of the Australian data set, this is as consistent as we can make the measure with U.S. studies, which have generally used annual earnings of spouses (Brines 1994; Greenstein 2000).

We used the reports by each spouse of gross income to compute the proportion of income contributed by the husband. Men contributed an average of $70 \%$ of family income (see table 1 above). In $29 \%$ of the couples, the man provided all the income; $44 \%$ were between all male provision and equal provision; $13 \%$ reported exactly equal provision of income (this suspect figure is discussed below); in $9 \%$ women provided more than men but men contributed some; and in $5 \%$ husbands provided none of the income. The reasonable number of cases throughout the range is sufficient to inspire some statistical confidence.

Control variables.-Attempts to isolate effects consistent with exchange theory should control for the usual hours of paid (market) work of both spouses, although no prior studies have done this. Without such controls, any negative effects of a spouse's relative earnings on his or her housework may simply be picking up the effects of hours of paid work. Other things being equal, those who work more hours in the market will work less in the home, consistent with the sociological "time availability" thesis and Becker's (1991) efficiency views mentioned above. To test the exchangebargaining view, we would want to know if earning less leads one to do

\footnotetext{
${ }^{14}$ Respondents were given the option of specifying an exact dollar amount of their income or of choosing among income brackets presented on a prompt card. Where respondents indicated their income bracket, we have used the midpoint of this bracket. Households in which either the husband or wife declined to answer the income question were excluded from the sample, as were households with total family income of zero or less (indicating business losses).
} 
more housework, even if one is working as many hours in the market as one's spouse, so each spouse's usual hours of market work is entered into our models. We would also want to isolate any special effects there might be of men's being temporarily unemployed or out of the labor force (above and beyond linear effects of hours of market work), so dummies for these statuses are also included. Homemaker status is captured by a dummy for the wife's being out of the labor force.

We control for combined weekly income of the couple to represent absolute ability of households to purchase substitutes for household work (although we also experiment with removing this from the equation and find it hardly affects our conclusions about effects of relative earnings). Because time-diary data are daily data and time use varies by day of the week, dummies for Saturday and Sunday were introduced-with weekdays the reference category. (However, we converted our dependent variable, time spent in housework, from hours per day to the metric of hours per week for ease of interpretation.) Number of children in various age ranges is also included. We also include dummies representing educational attainment for the spouse whose household work is being predicted. "University degree" signifies the completion of a university degree or higher. "Trade qualifications" describe the attainment of a vocational certificate, diploma, or the successful completion of apprenticeships. We include a final dummy variable for completion of secondary education, which in Australia entails about 12 years of study. The reference category is those who did not complete secondary education, with one caveat. Since in Australia trade qualifications can be attained without completing secondary school, those who dropped out of secondary school but attained trade qualifications were coded according to the latter credential. Age is included as a continuous variable. (We experimented with various ways of measuring age in results not shown, but differing methods had only trivial effects on the coefficients for relative income.)

We also included a dummy for cases where the two spouses reported exactly the same income, and both reported that the main source of this income was from self-employment rather than wages or salaries. Inspection of the date revealed that in 285 couples ( $13 \%$ of cases), the two spouses reported precisely equal incomes. It seemed implausible that so many couples had precisely the same earnings. Closer inspection revealed that, in a number of these cases, both spouses reported that the main source of the income was a business (rather than wages or salaries earned as an employee). We believe that these are largely cases of income from selfemployment where the couple reports it to tax authorities (and also to surveys) as equally split because of a feature of the Australian tax code. The Australian tax system of progressive brackets is more individually than family based compared to the U.S. system. Tax codes allow income 
from businesses to be split equally between spouses, even if one spouse is the only one who actually works in the business. This substantially reduces tax liability for some affluent couples. We suspect that a number of couples who report their income this way to tax authorities are also reporting it this way for the survey. However, treating a wife who does not actually work in the business as having equal earnings seems a distortion of her exchange or threat-point situation. Thus, to control for any distortion caused by these cases, we entered a dummy variable coded "1" if both the following conditions were met: their income was equal, and both reported that something other than wages or salaries was the main source. (Since those with unearned income such as government benefits and investments as their main source of income have been eliminated, this leaves only those with earned self-employment income in this category.) Some sensitivity analyses also include various measures of health.

\section{FINDINGS: HOW GENDER AND RELATIVE EARNINGS AFFECT HOUSEHOLD WORK IN AUSTRALIA}

Table 2 presents results from OLS regressions predicting unpaid work, with separate models for husbands and wives. The dependent variable in these models is domestic work in hours per week, including all housework and outdoor yard work (excluding child care and shopping).

\section{Effects of Spouses' Relative Earnings}

The discussion focuses on the effects of the variable of most theoretical interest, the proportion of family income contributed by the husband. To test for nonlinearities we entered this in linear and squared form. In results not shown, we entered the cube of this measure as well but, consistent with Brines (1994), it did not show significant effects on either men's or women's unpaid work. In the exchange-bargaining view, as one's earnings relative to the spouse's increase, so does one's ability to bargain for doing less housework and getting the spouse to do more. Thus the prediction is a negative effect of the husband's provision of income on men's unpaid labor time and a positive effect on women's.

Table 2 shows significant nonlinear effects of the husband's share of income on the wife's unpaid work. Given the nonlinearity, we computed a plot of predicted hours of unpaid work across the range of the husband's share of income, with other variables taken at their mean or at a modal category for dummy variables. Figure 1 shows the predicted hours of unpaid work per week for women and men across the range of values of the husband's share of income. The values were computed from the re- 
TABLE 2

OLS Regression of Australian Husbands' and Wives' Weekly Hours of Housework on Husband's Share of COUPLE's InCOME ANd Controls

\begin{tabular}{|c|c|c|c|}
\hline Variable & Husbands & Wives & $\begin{array}{c}\text { Gender } \\
\text { Difference } \mathrm{T}\end{array}$ \\
\hline Husband's share of income (scaled 0-1) .... & $\begin{array}{l}3.853 \\
(5.243)\end{array}$ & $\begin{array}{r}-21.653^{*} \\
(5.969)\end{array}$ & 3.21 \\
\hline Husband's share of income ${ }^{2}$ & $\begin{array}{l}-2.783 \\
(4.433)\end{array}$ & $\begin{array}{r}21.781^{*} \\
(5.041)\end{array}$ & -3.66 \\
\hline Combined weekly income $^{\mathrm{a}}$ & $\begin{array}{c}-.001 \\
(.001)\end{array}$ & $\begin{array}{r}-.0004 \\
(.001)\end{array}$ & -.74 \\
\hline 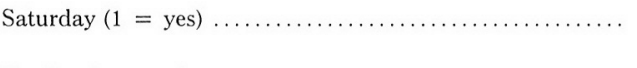 & $\begin{array}{l}7.281^{*} \\
(.800)\end{array}$ & $\begin{array}{l}2.438^{*} \\
(.911)\end{array}$ & 3.99 \\
\hline Sunday $(1$ = yes $)$ & $\begin{array}{c}9.201^{*} \\
(.812)\end{array}$ & $\begin{array}{l}3.456^{*} \\
(.925)\end{array}$ & 4.67 \\
\hline \multicolumn{4}{|l|}{ Number of children: } \\
\hline Less than two years old. & $\begin{array}{l}.297 \\
(.786)\end{array}$ & $\begin{array}{r}-1.744 \\
(.898)\end{array}$ & 1.71 \\
\hline Ages $2-4 \ldots \ldots \ldots \ldots \ldots \ldots$ & $\begin{array}{c}1.384^{*} \\
(.672)\end{array}$ & $\begin{array}{l}1.044 \\
(.769)\end{array}$ & .33 \\
\hline Ages $5-9 \ldots \ldots$. & $\begin{array}{l}.665 \\
(.447)\end{array}$ & $\begin{array}{l}1.99 * \\
(.510)\end{array}$ & -1.95 \\
\hline Ages $10-14 \quad \ldots \ldots \ldots \ldots \ldots$ & $\begin{array}{l}.164 \\
(.425)\end{array}$ & $\begin{array}{l}.417 \\
(.484)\end{array}$ & -.39 \\
\hline Husband's usual weekly hours of paid work ............ & $\begin{array}{r}-.097 * \\
(.022)\end{array}$ & $\begin{array}{l}.004 \\
(.25)\end{array}$ & -.40 \\
\hline Wife's usual weekly hours of paid work. & $\begin{array}{l}.069 * \\
(.023)\end{array}$ & $\begin{array}{r}-.19 * \\
(.027)\end{array}$ & 7.32 \\
\hline \multicolumn{4}{|l|}{ Respondent has: } \\
\hline University degree $(1=$ yes $) \ldots$ & $\begin{array}{l}1.27 \\
(.826)\end{array}$ & $\begin{array}{c}-1.195 \\
(1.039)\end{array}$ & 1.86 \\
\hline Trade qualifications $(1=$ yes $) \ldots \ldots$ & $\begin{array}{l}-.316 \\
(.664)\end{array}$ & $\begin{array}{c}-1.499 \\
(1.689)\end{array}$ & .65 \\
\hline High school diploma $(1=$ yes $) \ldots \ldots \ldots \ldots$ & $\begin{array}{r}-1.039 \\
(.948)\end{array}$ & $\begin{array}{l}-.466 \\
(1.014)\end{array}$ & -.41 \\
\hline Respondent's age $\ldots \ldots \ldots \ldots \ldots \ldots \ldots \ldots \ldots \ldots$ & $\begin{array}{l}.16^{*} \\
(.037)\end{array}$ & $\begin{array}{l}.337 * \\
(.042)\end{array}$ & -3.16 \\
\hline Husband unemployed ( $1=$ yes $)$ & $\begin{array}{c}5.43 * \\
(2.611)\end{array}$ & $\begin{array}{l}-1.63 \\
(2.976)\end{array}$ & 1.78 \\
\hline Husband out of labor force $(1=$ yes $) \ldots . .$. & $\begin{array}{l}8.8^{*} \\
(3.955)\end{array}$ & $\begin{array}{r}-1.576 \\
(4.493)\end{array}$ & 1.73 \\
\hline Wife out of labor force $(1=$ yes $) \ldots \ldots \ldots \ldots \ldots$ & $\begin{aligned}-.278 \\
(.985)\end{aligned}$ & $\begin{array}{r}-2.709 * \\
(1.120)\end{array}$ & 1.63 \\
\hline Evenly split self-employment income $(1=$ yes $) \ldots \ldots \ldots \ldots$ & $\begin{array}{l}-1.54 \\
(1.406)\end{array}$ & $\begin{array}{c}6.498 * \\
(1.599)\end{array}$ & -3.78 \\
\hline Constant & $\begin{array}{c}4.894 \\
(2.533)\end{array}$ & $\begin{array}{l}15.842 \\
(2.850)\end{array}$ & -2.87 \\
\hline$\ldots \ldots \ldots \ldots$ & .12 & .16 & \\
\hline
\end{tabular}

Note. $-N=2,244$. SEs are in parentheses.

" The average weekly income of both husband and wife given in Australian dollars.

* $P \leq .05$ 


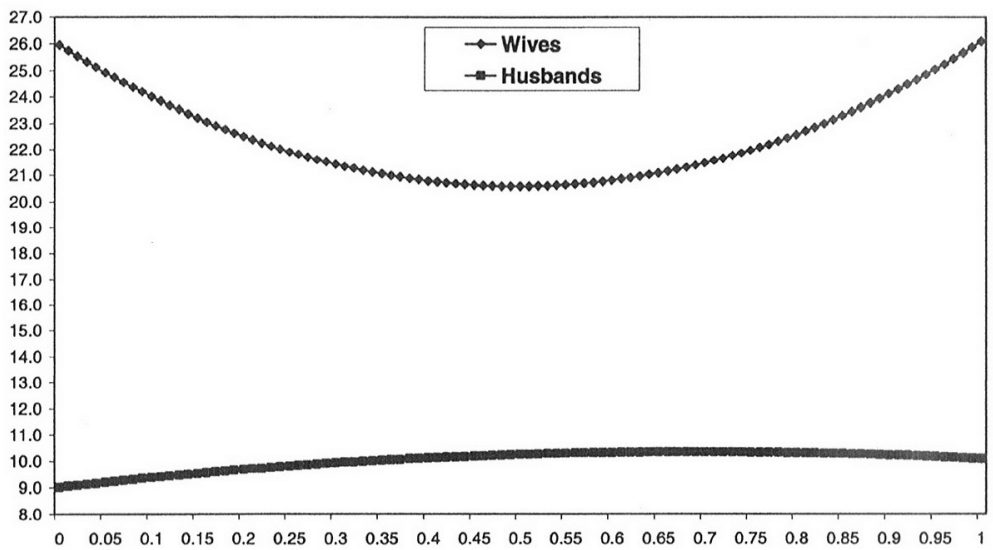

FIG. 1.-Australian wives' and husbands' predicted weekly hours of housework by husband's share of couple's income. The predicted values are computed from husbands' and wives' models in table 2, setting total couple's income, age, and hours of paid work to their observed means and assuming both spouses were high school graduates (with no trade qualifications) and had one child ages 2-4 and one child ages 5-9. Note that these predicted values do not set husbands' paid hours equal to wives', but set wives' at their observed mean and husbands' at their observed mean.

gressions in table 2, assuming that it was not a weekend day; that the couple had only one child between two and four years of age and one child between five and nine years of age; that both spouses had completed secondary education (but did not have trade qualifications or a university degree); and that both spouses were employed (and thus in the labor force). Other variables (family income and each spouse's age and usual hours of paid work) were set at their mean from table 1 . The values assumed for variables (other than the proportion of income contributed by the husband) affect the level but not the shape of the relationship depicted in figure 1, since the regression included no interactions with husband's share of income. Figure 1 shows that men's hours of unpaid work are virtually unaffected by relative contributions to income but that women's unpaid hours of work are minimized when spouses contribute approximately equal income. Even holding constant hours of market work of both spouses, women's housework increases about six hours per week over the range that goes from women's contributing equal income to their complete dependence on the man's money. This movement (on the right half of fig. 1) is consistent with bargaining theory.

However, figure 1 also shows where gender trumps money-based bargaining. Between the point where women contribute about half the income and the point where they provide all of it, money is not parlayed into reduced household work for women. On the contrary, in this range, as 
women provide more of the income, their hours of unpaid work go up by five to six hours per week. Here (in the left half of the graph in fig. 1), the negative slope expressing the relation between the husband's share of income and the wife's unpaid work is the opposite of what would be predicted by exchange-bargaining theory. As things move to greater male economic dependency where men are not enacting masculinity through providing money, women pick up more of the housework-as if to neutralize the man's deviance. This effect is not coming entirely from unemployed men or those not in the labor force, as the effect exists while controlling for both these statuses of husbands. However, we should remember that only $14 \%$ of couples were in the range where women provided more than half the income.

We undertook a number of sensitivity tests to be confident of our conclusion that the relationship between the proportion of income husbands contribute and wives' housework is curvilinear and centered on approximately equal contributions. The results of these analyses are not shown but are available upon request from the first author. We created dummies for relative income and found a shape similar to figure 1. As an alternative we generated a median spline trace of the relationship. To hold other variables constant, we residualized both relative income contribution and women's hours of household work (residuals from all other independent variables in our models). We then plotted the median (residualized) hours of women's housework for each small increment of husband's share of income. The shape was similar to figure 1 . We also reestimated the model in table 2 separately for the major subcomponents of houseworkcooking, laundry, and cleaning. For men, contribution to income never had a significant effect, as with all unpaid work. But for women, we got the same basic shape shown in figure 1 for cooking, laundry, and cleaning. We were also interested in whether the shape of the predicted values in figure 1 was being driven largely by outliers, as Gupta's (1999b) replication of Brines shows to be true of her 1994 analysis. We reran the wives' models from table 2 but eliminated the $3 \%$, and then the $5 \%$, of the sample in which the men contributed the lowest proportion of family income. We continued to get a shape like that in figure 1 . Nor is the shape of the relative earnings effect changed by controlling for a number of measures of health in the data. Our independent variable was based on annual income for those for whom most of it came from earnings, not a wage. One's annual income is a function of the hourly wage as well as of how many hours one worked in the year. Economists generally test bargaining theories with wage rates (or predicted wage rates); here we followed the sociologists' convention of using annual earnings. However, we tried estimating a wage rate for each spouse by assuming that currently employed individuals were employed all year, converting annual to weekly 
earnings, and dividing this by usual weekly hours of market work. We made a measure parallel to our measure of relative income, computing his proportion of her wage plus his wage. Running our basic model (without the controls for unemployment or labor force status, which are constant among the currently employed) shows a shape similar to that in figure 1 but in which the left-hand part (interpreted as gender deviance neutralization) is less dramatic. Thus, the shape in figure 1 is quite robust to procedure.

What about effects on men's housework? Table 2 shows that the proportion men contribute to the couple's earnings has no significant effect on their unpaid work time. (In results not shown, we removed the squared term and tested the linear effect of relative earnings, and it was also not significant.) Men's household work time is unresponsive to changes in which spouse is providing how much income. This is contrary to the prediction of bargaining theory. When we put this together with the findings for women, we see that, from male providership to approximately equal incomes, women can use bargaining to reduce their own housework but not to increase men's. It also suggests there is less resistance to women's becoming less "feminine" than there is to men's enacting a traditionally female activity such as housework: women either do not try or cannot successfully bargain to get men to do more housework. This is one way gender constrains bargaining. In these Australian data, we did not find the curvilinear effect of income contributions on men's housework found in American data by Brines (1994) and Greenstein (2000).

\section{Effects of Gender through Factors Other than Income Contribution}

Let us back up and examine the total difference between Australian husbands' and wives' housework and use predicted values from means (table 1) and regression results to consider various mechanisms through which this difference occurs. Men average 11 and women 23 hours of housework (exclusive of child care) per week (table 1), for a difference of 12 hours per week. What difference would a movement in hours of paid work between the completely traditional division of labor and both having fulltime employment make? Calculations from the regression results show that, holding other things constant, a woman's weekly housework hours are reduced 7.6 hours and a man's increased 2.7 as a couple moves from the wife's not being employed with a husband working for pay 40 hours per week to a situation where both work for pay 40 hours weekly. ${ }^{15}$ (Actual

\footnotetext{
${ }^{15}$ We have held relative contribution to income at its observed mean for this calculation. Of course, a change in hours at the same wage rate would increase women's contribution to income, so the total effect of hours is probably understated here.
} 
hours of paid work per week are 24 for women and 47 for men; see table 1.) Recall that the effects of contributions to income were curvilinear. The approximate magnitude of the bargaining effect was that moving from the man's providing all the money to the woman's providing an equal share decreased women's housework by about 6 hours per week, while the gender display effect was that moving from equal income contribution to the woman's providing all the income added about 5 to 6 hours per week to women's housework (fig. 1). (As noted above, in the average couple, the husband provides $70 \%$ of the income.) Finally, what about effects of gender that do not flow through spousal differences in paid work or income provision? We could think of these as ascription by gender per se. How do these effects compare in magnitude to the effects of various hypothetical movements in hours and income provision considered above? To answer this question, we used the regression results in table 2 to generate predicted amounts of women's and men's unpaid work time for various values of independent variables. Our choice of values of the independent variables reflect the hypothetical scenario that men and women have equal earnings (so husband's share of income is scored .5 and its square is .25) and each spouse works 40 hours per week in paid work. (Of course, it is important to recognize that we are predicting in extremes of the existing range for this data, and that this equality in market work and pay is even more rare in Australia than in the United States.) We have set education to completion of secondary school (with no trade qualifications or university degree), since this is the modal value for men and women. Dummies for being unemployed or not being in the labor force were set to zero. Age was set at its mean for each sex. Total household earnings was set to its mean. We make predictions for a couple with one child under two years old. The predicted score for men and women will differ as a function of a combination of differences between the intercepts and slopes from the male and female regressions. ${ }^{16}$ The result of this exercise is that, when market hours and earnings are equal and the couple has one child less than two years of age, the prediction is 10 hours of household work for men and 13 for women, a sex difference of three

\footnotetext{
16 As Jones and Kelley's (1984) work on decomposition has shown, the distinction between the portion of a gap between groups explained by intercepts and slopes is not meaningful, since how much is allocated to intercepts versus slopes changes if we change the zero point on an independent variable, including if we change the reference category for a dummy variable. Thus, it is most appropriate to combine these two effects to see the effects of sex that operate through something other than group differences on independent variables.
} 
hours. ${ }^{17}$ This gender ascription is certainly nontrivial, although smaller than the maximum magnitude of the effects of paid hours and relative income discussed above. Of course, couples' assignment of responsibility for hours of paid work is itself probably based on some combination of gender ascription and differential potential wage rates (not analyzed here).

\section{DISCUSSION: GENDER AND BARGAINING IN AUSTRALIA AND THE UNITED STATES}

Before reaching theoretical conclusions, we stop to consider how our findings corroborate or differ from those found in research on the U.S. data. In the Australian data, relative earnings had no significant linear or curvilinear effect on men's hours of housework. In contrast, Brines (1994) and Greenstein (2000) found a curvilinear relationship for men in the United States. As men's earnings relative to their wives decrease from providing all the money to providing half, men increase their housework (consistent with exchange predictions); but at equality the curve inflects, and with the movement from equality to women providing all the money, men decrease housework (consistent with gender deviance neutralization predictions). For women, Brines and Greenstein found a linear relationship in U.S. data between spouses' relative earnings and women's housework, consistent with exchange theory: as the woman earns more relative to her husband, her housework decreases, even net of total household income and her employment status. The Australian data also found this decrease of her housework as men's proportion of earnings decreased but only up to the point of equality. Again, the curve inflects at about equality; with the movement from equality to women providing all the money, Australian women increase the amount of housework they do, contrary to exchange-theory predictions.

The initial question we faced was whether the differences are true crossnational differences or whether they result from differences in the measurement of variables or in the regression specification. To try to get to the bottom of this, we undertook an analysis of the U.S. NSFH data used by Greenstein. The results are shown in the appendix table A1 and figure A1. We redid Greenstein's analysis but with model specifications as close to our table 2 as permitted by the data. In results not shown, we also reran the Australian regressions using procedures as close as possible to those used by Greenstein and Brines in their analyses of the U.S. data.

\footnotetext{
${ }^{17}$ If there are no children, there is actually a larger predicted gender gap of five hours. However, recall that we excluded child care time from the dependent variable. If the regressions in table 2 are run including child care in the dependent variable, then these fitted value calculations show a larger gender gap with than without children.
} 
Our conclusion is that there is a real national difference that centers on the nonlinearity in the effect of relative earnings on women's housework that is present in the Australian but not the U.S. data. No manipulation of the Australian data to make things more similar to Brines's or Greenstein's specifications makes the Australian female curvilinearity go away (results not shown). Appendix table A1 shows that NSFH regressions, as similar to table 2 on the Australian data as the data allowed, do not find this nonlinearity for women. In the United States, women do less housework as they earn more, reducing it by as much as 5 hours per week as the husband's proportion of joint earnings goes from 0 to 1 (see app. table A1 and fig. A1). In Australia this is true for the $86 \%$ of couples in which his income is higher than hers, too, and the magnitude is similar. But the important national difference is that Australian women respond to earning more than their husbands by increasing their housework, as if to make up for the gender deviance of female breadwinning and their husbands' dependence on this. While only $14 \%$ of couples are in the section of the distribution where men contribute less than half the income, the effect is not merely in the extreme tail; we cannot make it go away by deleting the $2 \%-3 \%$ of the cases where men earn nothing, or the $2 \%$ or $3 \%$ of cases where men's relative earnings are lowest. These analyses make it clear that the Australia-U.S. differences for women are not caused by specification differences between our study and Brines's or Greenstein's. We believe they are real national differences.

There are also differences between Australian and U.S. men, although these are less dramatic. No manipulation of the Australian data to make procedures more similar to the U.S. analysis produces the curvilinearity for Australian men that Brines (PSID) and Greenstein (NSFH) found for the United States (results not shown). Australian men's participation in housework is impervious to their wives' earnings. While our analysis of the NSFH data replicates Greenstein's finding of a nonlinear effect of relative contribution to income on men's housework (see app. table A1 and fig. A1), we find this nonlinearity to be very "fragile," disappearing if we delete just the $2 \%-3 \%$ of cases where men contribute absolutely no earnings (results not shown). Recall that Gupta (1999b) shows that the same thing is true of Brines's (1994) PSID analysis. Thus, we conclude that the U.S. phenomenon of men's responding to economic dependence on women by decreasing housework is real but that it comes only from the extreme tail of the men's earnings distribution. Moreover, the curves are very shallow for U.S. men. Maximal movements of relative earnings do not increase or decrease American men's housework more than 2.5 hours per week. (This can be seen in the men's curve in app. fig. A1. Similar calculations not shown from Brines [1994] and Greenstein [2000] show the shallowness of the slopes for men.) Thus, the U.S. situation is 
really not so different from the Australian one in which there are no linear or curvilinear effects of relative earnings on men's housework. In either country, men's housework is much more impervious to relative earnings than women's is.

We cannot absolutely rule out the possibility that the differences are caused by the use of (superior) time-diary measures of housework in Australia versus simple questions on hours per week in the two U.S. studies. Unfortunately, as mentioned above, the only U.S. data sets with timediary information for a recent sample do not have data on earnings, so those data cannot resolve the issue. However, while it is possible that it is the way housework is measured that causes the difference, it seems unlikely. One could imagine that simple questions about hours per week could produce a "compensatory" underreport of housework for men who are already gender deviant by virtue of low relative earnings. But it is less plausible that time diaries would produce a "compensatory" overreporting of housework by women in these "deviant" couples if the housework isn't really being done, particularly since social-desirability bias is probably greater with simple questions than with time diaries. Thus, while the U.S. men's curvilinearity could result from greater underreporting of housework by men in a "deviant" situation, we doubt overreporting by women in "deviant" couples can explain the female curvilinearity in Australia. It is less important to resolve whether the U.S. men's curvilinearity results from underreporting, since the effect is small anyhow and applies largely to outliers on the spectrum of relative earnings; neither of these limits is true for the Australian women. Therefore, the national difference we would emphasize-because of its large size, its applicability beyond the tail of the distribution, and the unlikelihood that it is simply an artifact of the research methods-is the curvilinearity in the response of women's housework to relative earnings in Australia.

What explains the fact that American women reduce their own housework across the whole range of relative earnings while Australian women do so only to the point of equality but do more housework as their relative contribution to income rises above $50 \%$, as if to compensate for the gender deviance of earning more than their husbands? We can only speculate on the basis of our knowledge of macrosociological differences between the two societies. There are many institutional differences that make women's primary breadwinning more deviant in Australia than in the United States. Most Australian women with children work part-time (ABS 2000), whereas many American mothers work full-time hours even when their children are preschoolers (Casper and Bianchi 2002, p. 290). For example, in our Australian data, of all women with children in the household, only $20 \%$ were employed full-time (at least 35 hours per week), 39\% were employed part-time, and $40 \%$ were not employed. By contrast, in the U.S. 
NSFH data, $40 \%$ of mothers with children in the household were employed full-time (fully twice as many as in Australia), $25 \%$ were employed part-time, and 35\% were not employed. In Australia, the idea of a male breadwinner and a "family wage" for men was actually enshrined in law during decades of governmental wage setting, while for this same period it was assumed that women should be paid less because they had no dependents and were not family breadwinners (O'Connor, Orloff, and Shaver 1999; Ryan and Conlon 1975). It is then, we suspect, more deviant for women to be employed full-time and earn more than their husbands in the Australian case than in the U.S. case, and so this spawns more gender deviance neutralization in Australia. Moreover, because men do so little housework, it is hard for them to reduce it further to neutralize gender deviance.

What theoretical conclusions do we draw, looking across the evidence on the United States and Australia? First, we think there is substantial evidence consistent with exchange-bargaining theories in both societies. At least within the range where women's earnings don't exceed men's, women decrease their housework when they increase their earnings. This is not merely a matter of reducing housework hours in response to increased household income or their own increased hours of paid work, since the effects are estimated net of total household income and market hours, suggesting that women's bargaining power is affected by earnings. The theoretical conclusion is that efforts to reduce the sex gap in pay and move women toward equality of earnings with men are likely to reduce gender inequality in household work and thus time left for leisure. Money talks in marriage.

However, gender also has effects through mechanisms other than its effect on earnings. First, who provides how much of the income has no effect on men's unpaid work hours in Australia and very limited effects in the United States. Thus, while women can and do use income-based bargaining power to reduce their own housework, they either cannot or don't try to use it to increase their husbands' housework. They replace their time with purchased services, or housework simply goes undone. Second, calculating predicted hours of men's and women's housework from the regressions suggests that, even when men and women both work full-time and provide equal income, there is ascription by sex that leads women to do more housework than men. ${ }^{18}$ Finally, gender trumps money when women provide more income than their husbands. In this zone where men are earning less than their wives, Australian couples respond by having the wife do substantially more housework, and in U.S. couples,

${ }^{18}$ Although not shown, fitted values from the U.S. regression in the appendix show similar gender ascription. 
at least at the extremes of the distribution, men reduce their housework slightly. It is as if Australian wives and American men are trying to neutralize the deviance of the husband's economic dependence. The response by the Australian wives is larger, perhaps because women's employment is still more secondary in Australia and hence the deviance to be neutralized more striking. In this range gender expectations are powerful enough that women's money has an effect opposite that predicted by bargaining theory. Overall, we see roles for both gendered processes and gender-neutral processes of money-based bargaining. Sometimes money talks in spousal arrangements. But gender trumps money in the baseline amount of housework women do and also when traditional housework behavior seems needed to compensate for "gender deviance" in economic provision.

\section{APPENDIX}

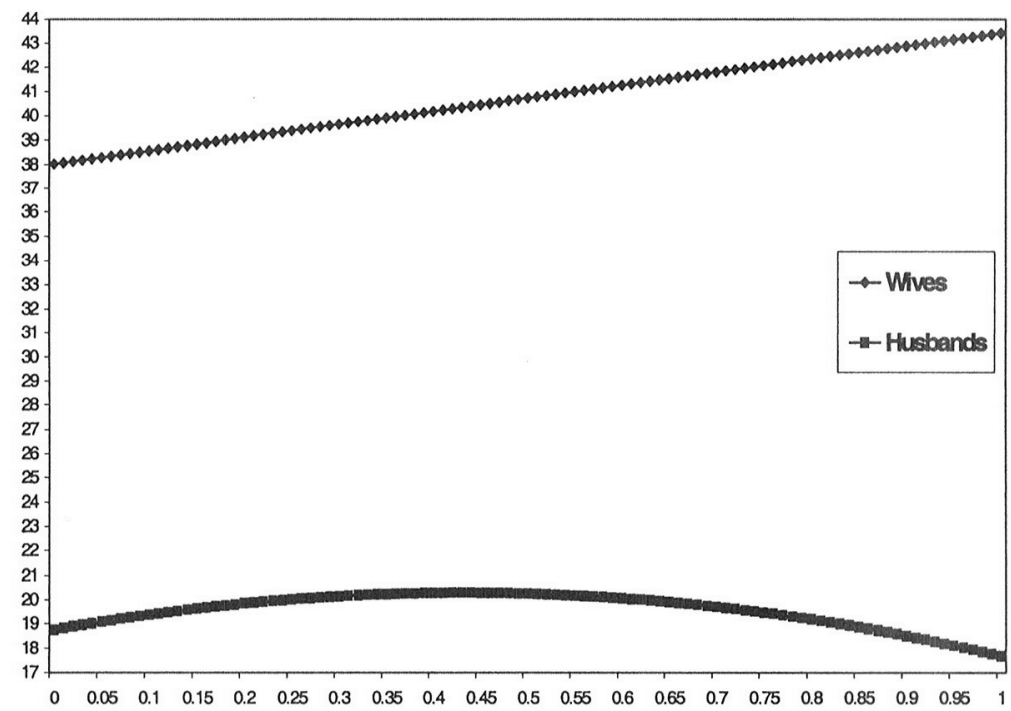

FIG. A1.-U.S. wives' and husbands' predicted hours of housework by husband's proportion of couple earnings, NSFH1 data. The predicted values are computed from models M1 for men and M2 for women (since the squared term was not significant) in appendix table A1. Total family income, age, and hours of paid work for husbands and wives were set to their observed means, and we assumed both spouses were high school graduates and had one child age 2-4 and one child age 5-9. Note that these predicted values do not set husbands' paid hours equal to wives, but rather set wives' at their observed mean and husbands' at their observed mean. 
TABLE A1

OLS Regressions of Husbands' and Wives' Weekly Hours of Housework on Husband's Share of Income and Controls, U.S. NSFH Data

\begin{tabular}{|c|c|c|c|c|c|c|}
\hline \multirow[b]{2}{*}{ VARIABLE } & \multicolumn{2}{|c|}{ HusBandS } & \multicolumn{2}{|c|}{ Wives } & \multicolumn{2}{|c|}{$\begin{array}{l}\text { GENDER DIF- } \\
\text { FERENCE T }\end{array}$} \\
\hline & M1 & M2 & M1 & M2 & M1 & M2 \\
\hline $\begin{array}{l}\text { Husband's share of in- } \\
\text { come (scaled } 0-1) \ldots\end{array}$ & $\begin{array}{c}7.088 \\
(5.462)\end{array}$ & $\begin{array}{c}-2.729 * \\
(1.528)\end{array}$ & $\begin{array}{r}-2.647 \\
(7.31)\end{array}$ & $\begin{array}{l}5.384 * * * \\
(2.056)\end{array}$ & 7.38 & -4.83 \\
\hline $\begin{array}{l}\text { Husband's share of in- } \\
\text { come }^{2} \ldots \ldots \ldots \ldots \ldots \ldots\end{array}$ & $\begin{array}{c}-8.176^{*} \\
(4.368)\end{array}$ & & $\begin{array}{c}6.694 \\
(5.847)\end{array}$ & & -9.09 & \\
\hline $\begin{array}{l}\text { Logged couples' annual } \\
\text { income (US\$) } \ldots \ldots \ldots .\end{array}$ & $\begin{array}{l}-.125 \\
(.324)\end{array}$ & $\begin{array}{l}-.09 \\
(.323)\end{array}$ & $\begin{array}{c}-1.149 * * * \\
(.436)\end{array}$ & $\begin{array}{c}-1.177 * * * \\
(.435)\end{array}$ & 1.99 & 2.08 \\
\hline $\begin{array}{l}\text { Number of children: } \\
\text { Less than two years } \\
\text { old } \ldots \ldots \ldots \ldots \ldots \ldots \ldots\end{array}$ & $\begin{array}{l}2.205 * * * \\
(.723)\end{array}$ & $\begin{array}{l}2.2 * * * \\
(.723)\end{array}$ & $\begin{array}{l}4.707 * * * \\
(.97)\end{array}$ & $\begin{array}{l}4.712 * * * \\
(.97)\end{array}$ & -1.69 & -1.69 \\
\hline Ages $2-4 \ldots \ldots \ldots \ldots$ & $\begin{array}{l}1.977 * * * \\
(.576)\end{array}$ & $\begin{array}{l}1.91 \% * * \\
(.575)\end{array}$ & $\begin{array}{l}4.91 \text { **** } \\
(.771)\end{array}$ & $\begin{array}{l}4.965 * * * \\
(.77)\end{array}$ & -3.12 & -3.26 \\
\hline Ages $5-9 \ldots \ldots \ldots$ & $\begin{array}{l}1.22 * * * \\
(.471)\end{array}$ & $\begin{array}{l}1.154 * * \\
(.47)\end{array}$ & $\begin{array}{l}4.565 * * * \\
(.629)\end{array}$ & $\begin{array}{l}4.62 * * * \\
(.627)\end{array}$ & -4.59 & -4.74 \\
\hline Ages $10-14 \quad \ldots \ldots \ldots \ldots$ & $\begin{array}{l}.388 \\
(.506)\end{array}$ & $\begin{array}{l}.366 \\
(.506)\end{array}$ & $\begin{array}{l}2.761 * * * \\
(.679)\end{array}$ & $\begin{array}{l}2.779 * * * \\
(.679)\end{array}$ & -2.87 & -2.92 \\
\hline $\begin{array}{l}\text { Husband's usual } \\
\text { weekly hours of paid } \\
\text { work } \ldots \ldots \ldots \ldots \ldots \ldots\end{array}$ & $\begin{array}{l}-.089 * * * \\
(.030)\end{array}$ & $\begin{array}{l}-.089 * * * \\
(.03)\end{array}$ & $\begin{array}{l}.126 * * * \\
(.041)\end{array}$ & $\begin{array}{l}.126 * * * \\
(.041)\end{array}$ & -2.57 & -2.57 \\
\hline $\begin{array}{l}\text { Wife's usual weekly } \\
\text { hours of paid } \\
\text { work ............... }\end{array}$ & $\begin{array}{l}.043 \\
(.028)\end{array}$ & $\begin{array}{l}.051 * \\
(.027)\end{array}$ & $\begin{array}{l}-.189 * * * \\
(.037)\end{array}$ & $\begin{array}{l}-.196 * * * \\
(.036)\end{array}$ & 4.12 & 4.41 \\
\hline $\begin{array}{l}\text { Respondent has: } \\
\text { University degree }(1= \\
\text { yes }) \ldots \ldots \ldots \ldots \ldots \ldots\end{array}$ & $\begin{array}{c}-2.216^{*} \\
(1.153)\end{array}$ & $\begin{array}{c}-2.156^{*} \\
(1.153)\end{array}$ & $\begin{array}{l}-9.866 * * * \\
(1.643)\end{array}$ & $\begin{array}{l}-9.912 * * * \\
(1.643)\end{array}$ & 2.70 & 2.78 \\
\hline $\begin{array}{l}\text { Some college }(1= \\
\text { yes }) \ldots \ldots \ldots \ldots \ldots\end{array}$ & $\begin{array}{r}.331 \\
(1.169)\end{array}$ & $\begin{array}{r}.388 \\
(1.169)\end{array}$ & $\begin{array}{l}-6.066^{* * *} \\
(1.612)\end{array}$ & $\begin{array}{l}-6.101 * * * \\
(1.612)\end{array}$ & 3.38 & 3.45 \\
\hline $\begin{array}{l}\text { High school diploma } \\
\qquad(1=\text { yes }) \ldots \ldots \ldots \ldots\end{array}$ & $\begin{array}{l}-.274 \\
(1.126)\end{array}$ & $\begin{array}{l}-.249 \\
(1.126)\end{array}$ & $\begin{array}{c}-2.528 * \\
(1.532)\end{array}$ & $\begin{array}{l}-2.53 * \\
(1.532)\end{array}$ & 1.06 & 1.08 \\
\hline Respondent's age ....... & $\begin{array}{c}-.081 * \\
(.041)\end{array}$ & $\begin{array}{l}-.085 * * \\
(.041)\end{array}$ & $\begin{array}{l}.112 * \\
(.057)\end{array}$ & $\begin{array}{l}.115 * * \\
(.057)\end{array}$ & -1.68 & -1.72 \\
\hline $\begin{array}{l}\text { Husband unemployed } \\
\qquad(1=\text { yes }) \ldots \ldots \ldots \ldots\end{array}$ & $\begin{array}{c}2.585 \\
(2.479)\end{array}$ & $\begin{array}{c}2.088 \\
(2.466)\end{array}$ & $\begin{array}{l}8.641 \text { *** } \\
(3.316)\end{array}$ & $\begin{array}{l}9.054 * * * * \\
(3.297)\end{array}$ & .50 & -.11 \\
\hline $\begin{array}{l}\text { Husband out of labor } \\
\quad \text { force }(1=\text { yes }) \ldots \ldots\end{array}$ & $\begin{array}{l}-.003 \\
(2.729)\end{array}$ & $\begin{array}{l}-.463 \\
(2.719)\end{array}$ & $\begin{array}{c}-1.581 \\
(3.65)\end{array}$ & $\begin{array}{c}-1.19 \\
(3.634)\end{array}$ & .34 & -.20 \\
\hline
\end{tabular}


TABLE A1 (Continued)

\begin{tabular}{|c|c|c|c|c|c|c|}
\hline \multirow[b]{2}{*}{ VARIABLE } & \multicolumn{2}{|c|}{ HUSBANDS } & \multicolumn{2}{|c|}{ WiVES } & \multicolumn{2}{|c|}{$\begin{array}{l}\text { GENDER DIF- } \\
\text { FERENCE T }\end{array}$} \\
\hline & M1 & M2 & M1 & M2 & M1 & M2 \\
\hline \multicolumn{7}{|l|}{ Wife out of labor force } \\
\hline$(1=$ yes $) \quad \ldots \ldots \ldots \ldots$ & $\begin{array}{l}-.787 \\
(1.111)\end{array}$ & $\begin{array}{c}-1.094 \\
(1.1)\end{array}$ & $\begin{array}{l}-.718 \\
(1.488)\end{array}$ & $\begin{array}{l}-.467 \\
(1.472)\end{array}$ & -.40 & -.84 \\
\hline Constant ............... & $\begin{array}{l}23.012 * * * \\
(3.847)\end{array}$ & $\begin{array}{l}25.045 * * * \\
(3.693)\end{array}$ & $\begin{array}{l}40.238 * * * \\
(5.09)\end{array}$ & $\begin{array}{l}38.564 * * * \\
(4.876)\end{array}$ & 16.71 & 18.74 \\
\hline$R^{2} \ldots$ & .05 & .05 & .2 & .2 & & \\
\hline
\end{tabular}

Note. $-N=2,128$. SEs are in parentheses. Sample is restricted to married couples with complete information on variables and where neither is age 55 or older and neither reports a disability that limits paid employment. $\mathrm{T}$ is the $t$-statistic testing whether slope for husbands is different from that for wives.

$* P \leq .10$.

** $P \leq .05$.

*** $P \leq .01$

\section{REFERENCES}

ABS (Australian Bureau of Statistics). 1993. Time Use Survey Australia: User's Guide, Catalog no. 4150.0. Canberra: ABS. 2000. Labour Force Status and Other Characteristics of Families. Catalog no. 6224.0. Canberra: ABS.

Agarwal, Bina. 1997. "Bargaining and Gender Relations: Within and Beyond the Household." Feminist Economics 3 (1): 1-51.

Atkinson, Maxine P., and J. Boles. 1984. "WASP (Wives as Senior Partners)." Journal of Marriage and the Family 46:861-70.

Badgett, Lee, Pamela Davidson, and Nancy Folbre. 2000. "Breadwinner Dad, Homemaker Mom: An Interdisciplinary Analysis of Changing Gender Norms in the United States, 1977-1998." Manuscript. University of Massachusetts-Amherst.

Becker, Gary S. 1991. A Treatise on the Family. Cambridge, Mass.: Harvard University Press.

Bianchi, Suzanne M., Melissa A. Milkie, Liana C. Sayer, and John P. Robinson. 2000 "Is Anyone Doing the Housework? Trends in the Gender Division of Household Labor." Social Forces 79:191-228.

Bianchi, Suzanne M., John P. Robinson, and Liana C. Sayer. 2001. "Family Interaction, Social Capital, and Trends in Time Use Study." University of Maryland, Survey Research Center, College Park.

Bittman, Michacl, and Jocelyn Pixley. 1997. The Double Life of the Family: Myth, Hope, and Experience. Sydney: Allen \& Unwin.

Brines, Julic. 1994. "F.conomic Dependency, Gender, and the Division of Labor at Home." American Joumal of Sociology 100, no. 3 (November): 652-88.

Casper, Lynn, and Suzanne Bianchi. 2002. Continuity and Change in the American Family. Thousand Oaks, Calif.: Sage.

Coltrane, Scott. 2000. "Research on Household Labor: Modeling and Measuring the Social Embeddedness of Routine Family Work." Journal of Marriage and the Family 64 (4): 1208-33.

Cook, Karen, ed. 1987. Social Exchange Theory. Newbury Park, Calif.: Sage.

Fenstermaker (Berk), Sarah. 1985. The Gender Factory: The Apportionment of Work in American Households. New York: Plenum.

Fcrree, Myra, Judith Lorber, and Beth B. Hess, eds. 1998. Revisioning Gender. Lanham, Md.: Altamira. 
Frederick, Judith A. 1995. "As Time Goes By . . . The Time Use of Canadians." Catalogue no. 89-544-XPE. Ottawa: Statistics Canada.

Greenstein, Theodore N. 2000. "Economic Dependence, Gender, and the Division of Labor in the Home: A Replication and Extension." Journal of Marriage and the Family 62:322-35.

Gupta, Sanjiv. 1999a. "The Effects of Marital Status Transitions on Men's Housework Performance." Journal of Marriage and the Family 61:700-711.

1999b. "Gender Display? A Reassessment of the Relationship betwcen Men's Economic Dependence and Their Housework Hours." Paper presented at the annual meeting of the American Sociological Association, Chicago.

Heer, David. 1963. "The Measurement and Bases of Family Power: An Overview." Marriage and Family Living 25:133-39.

Hill, C. Russell, and Frank P. Stafford. 1985. "Parental Care of Children: 'Time Diary Estimates of Quantity, Predictability, and Variety." Pp. 415-37 in Time, Goods, and Well-Being, edited by F. Thomas Juster and Frank P. Stafford. Ann Arbor: University of Michigan Press.

Hochschild, Arlie R., with Anne Machung. 1989. The Second Shift: Working Parents and the Revolution at Home. New York: Viking.

Jones, F. L., and Jonathan Kelley. 1984. "Decomposing Differences between Groups: A Cautionary Note on Measuring Discrimination." Sociological Methods and Research 12:323-43.

Juster, F. Thomas. 1985. "The Validity and Quality of Time Use Estimates Obtained from Recall Diaries. Pp. 63-91 in Time, Goods and Well-Being, edited by F. Thomas Juster and Frank P. Stafford. Ann Arbor: University of Michigan Press.

Katz, Elizabeth. 1997. "The Intra-Household Economics of Voice and Exit." Feminist Economics 3 (3): 25-46.

Lundberg, Shelley, and Robert A. Pollak. 1993. "Separate Spheres Bargaining and the Marriage Market." Journal of Political Economy 101 (6): 988-1010.

. 1996. "Bargaining and Distribution in Marriage." Journal of Economic Perspectives 10:139-58.

Marini, Margeret Mooney, and Beth Anne Shelton. 1993. "Measuring Household Work: Recent Experience in the United States." Social Science Research 22:361-82.

McElroy, Marjorie. 1990. "The Empirical Content of Nash-Bargained Household Behavior." Journal of Human Resources 25 (4): 559-83.

McElroy, Marjorie B., and Mary Jane Horney. 1981. "Nash-Bargained Household Decisions: Toward a Generalization of the Theory of Demand." International Economic Review 22 (2): 333-49.

Molm, Linda, and Karen Cook. 1995. "Social Exchange and Exchange Networks." Pp. 209-35 in Sociological Perspectives on Social Psychology, edited by Karen Cook, Gary Fine, and James House. Needham Heights, Mass.: Allyn \& Bacon.

Niemi, Iris. 1993. "Systematic Error in Behavioural Measurement: Comparing Results from Interview and Time Budget Studies." Social Indicators Research 30:229-44.

O'Connor, Julia S., Ann Shola Orloff, and Sheila Shaver. 1999. States, Markets, Families: Gender, Liberalism and Social Policy in Australia, Canada, Great Britain and the United States. Cambridge: Cambridge University Press.

Pallie, Bernie. 1993. Estimating the Volume of Unpaid Activities in Canada, 1992: An Evaluation of Data from the General Social Survey. General Social Survey Working Paper no. 10. Ottawa: Statistics Canada.

Presser, Harriet B. 1994. "Employment Schedules among Dual-Earner Spouses and the Division of Labor by Gender." American Sociological Review 59 (June): 348-69.

Robinson, John P. 1985. "The Validity and Reliability of Diaries versus Alternative Time Use Measures." Pp. 33-62 in Time, Goods, and Well-Being, edited by F. 'Thomas Juster and Frank P. Stafford. Ann Arbor: University of Michigan Press. 


\section{American Journal of Sociology}

Robinson, John P., and Geoffrey Godbey. 1997. Time for Life: The Surprising Ways Americans Use Their Time. University Park: Pennsylvania State University Press.

Ross, Catherine E. 1987. "The Division of Labor at Home." Social Forces 65:816-33.

Ryan, Edna, and Anne Conlon. 1975. Gentle Invaders: Australian Women at Work. Melbourne: Penguin.

Scanzoni, John. 1979. "A Historical Perspective on Husband-Wife Bargaining Power and Marital Dissolution." Pp. 10-36 in Divorce and Separation, edited by G. Levinger and $O$. Moles. New York: Basic Books.

Shelton, Beth Anne. 1992. Women, Men, and Time: Gender Differences in Paid Work, Housework, and Leisure. New York: Greenwood Press.

Sorensen, Annemette, and Sara McLanahan. 1987. "Married Women's Economic Dependency, 1940-1980." American Journal of Sociology 93:659-87.

South, Scott J., and Glenna Spitze. 1994. "Housework in Marital and Nonmarital Households." American Sociological Review 59 (June): 327-47.

Sweet, James A., Larry L. Bumpass, and Vaughn A. Call. 1988. The Design and Content of the National Survey of Families and Households. University of Wisconsin, Center for Demography and Ecology, Madison.

West, Candace, and Don H. Zimmerman. 1981. "Doing Gender." Gender and Society 1:125-51.

Wilkie, Jane Riblett, Myra Marx Ferree, and Kathryn Strother Ratcliff. 1998. "Gender and Fairness: Marital Satisfaction in Two Earner Couples." Journal of Marriage and the Family 60:577-94. 